\title{
Innovative Use of Paper Industry Waste (Hypo Sludge) in Pervious Concrete
}

\author{
Er. Siddharth Talsania ${ }^{1}$, Dr. Jayeshkumar Pitroda ${ }^{2}$ \\ ${ }^{I}$ Director, Rajtrishul Construction Company Pvt. Ltd, Ahmedabad, Gujarat, India \\ ${ }^{2}$ Assistant professor, Civil Engineering Dept., B.V.M. Engineering College, Vallabh Vidyanagar, \\ Gujarat, India \\ jayesh.pitroda@bvmengineering.ac.in
}

\begin{abstract}
Hypo sludge is also known as paper industry waste. Paper making generally produces a large amount of solid waste. This paper mill sludge consumes a large percentage of local landfill space for each and every year. To reduce disposal and pollution problems emanating from these industrial wastes, it is most essential to develop profitable building materials from them. The quantity of sludge varies from mill to mill. This hypo sludge contains low calcium and maximum calcium chloride and minimum amount of silica. Hypo sludge behaves like cement because of silica and magnesium properties. So Hypo sludge may be used as partially replacement of cement. So we can use Hypo sludge as a partial replacement of cement in pervious concrete. In this research study the (OPC) cement has been replaced by hypo sludge accordingly in the range of $10 \%$ and $20 \%$ by weight of cement for 0.30, 0.35, and 0.40 water/cement ratio. The compressive strength test and flexural strength test was carried out for 7, 14 and 28 days to measure the compressive strength and flexural strength of concrete. So the aim of the investigation is to study the behaviour of pervious concrete while replacing the hypo sludge with different proportions in concrete. Test results have reflected, the compressive strength and flexural strength achieved up to $20 \%$ replacement of cement with hypo sludge will be optimum without effecting properties of fresh and hardened concrete.
\end{abstract}

Keywords: Hypo sludge, Compressive Strength, Flexural Strength, Eco-Friendly, Pervious Concrete, Industrial Waste, Low Cost, OPC Cement.

\section{INTRODUCTION}

Pervious concrete is a unique and effective solution to reduce the runoff from paved areas and recharging the ground water. Pervious concrete can uproot storm water more rapidly than conventional concrete. It is directly recharging the ground water so it eliminates the need of retention pond, swales and storm water management devices. It is also eliminate costly storm water detention vaults and piping systems. Thus reduce construction expenses, safety issues and maintenance cost. The waste management problem has already become severe in the world. The problem is compounded by the rapidly increasing amounts of industrial wastes of a complex nature and composition. Energy plays a crucial role in the growth of developing countries like India. In the context of low availability of non-renewable energy resources coupled with the requirements of large quantities of energy for building materials like cement, the importance of using industrial waste cannot be underestimated. Many research organizations are doing extensive work on waste materials concerning the viability and environmental suitability. Therefore, the main objective of this research study is to use hypo sludge materials to develop a pervious concrete mixture proportion and to improve the compressive strength and flexural strength of pervious concrete. The share of India to the world's total production of paper and paper products have been rising from $0.68 \%$ in 1981 to $0.84 \%$ in 1990 . This has increased further to $1.00 \%$ in 2000 . In 2010 , it accounts for about $2.25 \%$ of world's production contributed by the impressive growth of all varieties of paper and paperboard driven by multiple policy initiatives undertaken by the government.

\section{EXPERIMENTAL MATERIALS}

\subsection{Hypo Sludge}

Hypo Sludge is a waste material collected from the Paper Industry. It is used as cement replacement in producing concrete and was investigated on its chemical and physical properties. Construction 


\section{Er. Siddharth Talsania \& Dr. Jayeshkumar Pitroda}

material with natural resources now become limited and causes of air pollution and environmental problems. Hypo Sludge becomes a new innovation material that can be used as material to support the green technology. Hypo sludge behaves like cement because of silica and magnesium properties. This silica and magnesium improve the setting of the concrete. Its chemical investigation is done by Geotest house Baroda. Chemical properties and physical properties of hypo sludge are as per Table 1 and Table 2. Figure 1 show the hypo sludge which is collected from Rainbow Papers Limited, Gujarat.

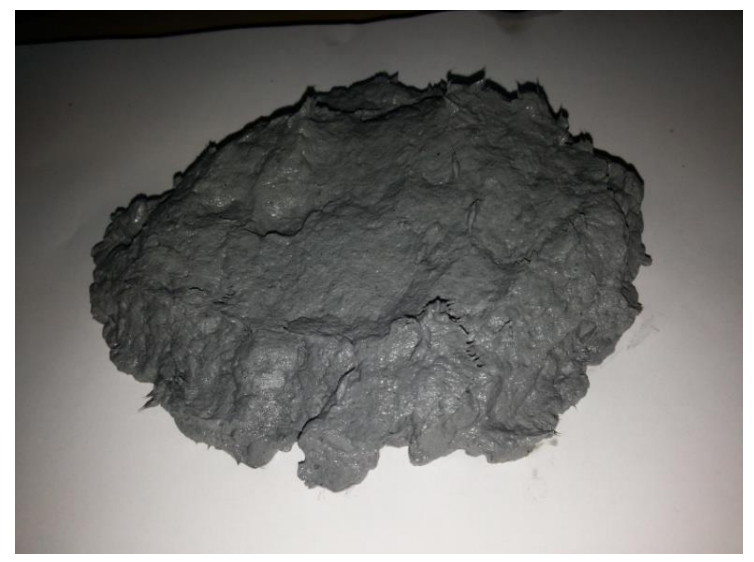

Figure1. Hypo Sludge

Source: Rainbow Papers Limited, Gujarat

Table1. Chemical properties of hypo sludge

\begin{tabular}{|l|l|l|}
\hline Sr. No. & Particulars & Proportion \\
\hline 1. & Silicon dioxide $\left(\mathrm{SiO}_{2}\right)$ & $9.27 \%$ \\
\hline 2. & Aluminum oxide $\left(\mathrm{Al}_{2} \mathrm{O}_{3}\right)$ & $1.45 \%$ \\
\hline 3. & Iron oxide $\left(\mathrm{Fe}_{2} \mathrm{O}_{3}\right)$ & $1.68 \%$ \\
\hline 4. & Calcium Oxide $(\mathrm{CaO})$ & $29.83 \%$ \\
\hline 5. & Magnesium Oxide $(\mathrm{MgO})$ & $4.28 \%$ \\
\hline 6. & Loss on Ignition & $49.24 \%$ \\
\hline
\end{tabular}

Source: Geo Test House, Baroda, Gujarat, India

Table2. Physical property of hypo sludge

\begin{tabular}{|l|l|l|}
\hline Sr. No. & Particulars & Proportion \\
\hline 1. & Specific gravity & 2.82 \\
\hline
\end{tabular}

Source: Geo Test House, Baroda, Gujarat, India

\subsection{Cement (OPC)}

The Ordinary Portland Cement of 53 grade Cement conforming to IS 12269:1987 is been used. Physical property and chemical composition of cement is as per Table 3 and Table 4.

Table3. physical properties of ordinary portland cement

\begin{tabular}{|l|l|l|}
\hline Property & Value for Cement & IS 12269:1987 \\
\hline Specific Gravity & 3.15 & $3.10-3.15$ \\
\hline Consistency & $28 \%$ & $30-35(\%)$ \\
\hline Initial setting time & $35 \mathrm{~min}$ & 30 minimum minutes \\
\hline Final setting time & $178 \mathrm{~min}$ & $600 \quad$ maximum minutes \\
\hline
\end{tabular}

Table4. Chemical compositions

OF ORDINARY PORTLAND CEMENT 53 GRADES (OPC)

\begin{tabular}{|l|l|l|}
\hline Sr No. & Particulars & Proportion \\
\hline 1. & Silicon Dioxide $\left(\mathrm{SiO}_{2}\right)$ & $21.77 \%$ \\
\hline 2. & Aluminum oxide $\left(\mathrm{Al}_{2} \mathrm{O}_{3}\right)$ & $2.59 \%$ \\
\hline 3. & Sulphur Trioxide $\left(\mathrm{SO}_{3}\right)$ & $02.41 \%$ \\
\hline 4. & Calcium Oxide $(\mathrm{CaO})$ & $57.02 \%$ \\
\hline 5. & Magnesium Oxide $(\mathrm{MgO})$ & $02.71 \%$ \\
\hline 6. & Ferric Oxide $\left(\mathrm{Fe}_{2} \mathrm{O}_{3}\right)$ & $0.65 \%$ \\
\hline
\end{tabular}

Source: Geo Test House, Baroda, Gujarat, India 


\subsection{Aggregate}

Aggregate occupies most of the volume of the concrete show they are the important constituents of concrete. They give body to the concrete, reduce shrinkage and effect economy. Two sizes of aggregate were used in this research work. Coarse aggregate used in the study were sieved to obtain required range. The physical properties of aggregate are describe in Table 5.

Two different sizes are listed below:

a. Aggregate with $100 \%$ passing $20 \mathrm{~mm}$ sieve and $100 \%$ retained on $10 \mathrm{~mm}$ sieve.

b. Aggregate with $100 \%$ passing $10 \mathrm{~mm}$ sieve and $100 \%$ retained on $4.75 \mathrm{~mm}$ sieve.

Table5. Physical properties of coarse aggregate

\begin{tabular}{|l|l|l|}
\hline Property & Aggregate & \\
\hline & $\mathbf{2 0} \mathbf{~ m m}$ & $\mathbf{1 0} \mathbf{~ m m}$ \\
\hline Fineness Modulus & 7.52 & 3.19 \\
\hline Specific Gravity & 2.75 & 2.65 \\
\hline Water Absorption & 1.82 & 1.30 \\
\hline
\end{tabular}

\subsection{Water}

Water is an important ingredient of concrete as it actually participates in the chemical reaction with cement. Since it helps to from the strength giving cement gel, the quantity and quality of water are required to be looked into very carefully.

\section{DESIGN MIX}

The mix proportion by using hypo sludge powder is given in Table 6 . The design mix of pervious concrete using hypo sludge is shown in Table 7 . For the design mix aggregate content is $1500 \mathrm{~kg} / \mathrm{m}^{3}$ and Cement: Aggregate ratio 1:4 is kept constant.

Table6. Mix proportion by using hypo sludge

\begin{tabular}{|c|c|c|c|c|}
\hline Mix & Aggregate Content & Cement Content & W/C Ratio & Cementitious Material \\
\hline $\operatorname{Mix}_{0.30}$ & \multirow[t]{3}{*}{$1500 \mathrm{~kg} / \mathrm{m}^{3}$} & \multirow[t]{3}{*}{$375 \mathrm{~kg} / \mathrm{m}^{3}$} & \multirow[t]{3}{*}{0.30} & 0\% Hypo Sludge \\
\hline H Mix1 & & & & $10 \%$ Hypo Sludge \\
\hline H Mix2 & & & & $20 \%$ Hypo Sludge \\
\hline $\mathbf{M i x}_{\mathbf{0 . 3 5}}$ & \multirow[t]{3}{*}{$1500 \mathrm{~kg} / \mathrm{m}^{3}$} & \multirow[t]{3}{*}{$375 \mathrm{~kg} / \mathrm{m}^{3}$} & \multirow[t]{3}{*}{0.35} & 0\% Hypo Sludge \\
\hline H Mix3 & & & & $10 \%$ Hypo Sludge \\
\hline H Mix4 & & & & $20 \%$ Hypo Sludge \\
\hline $\mathbf{M i x}_{\mathbf{0 . 4 0}}$ & \multirow[t]{3}{*}{$1500 \mathrm{~kg} / \mathrm{m}^{3}$} & \multirow[t]{3}{*}{$375 \mathrm{~kg} / \mathrm{m}^{3}$} & \multirow[t]{3}{*}{0.40} & 0\% Hypo Sludge \\
\hline H Mix5 & & & & $10 \%$ Hypo Sludge \\
\hline H Mix6 & & & & $20 \%$ Hypo Sludge \\
\hline
\end{tabular}

Table7. Design mix using hypo sludge

\begin{tabular}{|c|c|c|c|c|c|c|}
\hline \multicolumn{7}{|c|}{ Concrete Design Mix Proportions $\left(\mathrm{kg} / \mathrm{m}^{3}\right)$} \\
\hline \multirow[t]{2}{*}{ Mix } & \multirow{2}{*}{$\begin{array}{l}\text { W/C } \\
\text { Ratio }\end{array}$} & \multicolumn{5}{|c|}{ Quantity Requirement } \\
\hline & & Cement (kg) & $\begin{array}{ll}\text { Hypo } & \text { Sludge } \\
\text { (kg) } & \end{array}$ & $\begin{array}{l}\text { Aggregate } \\
10 \mathrm{~mm}(\mathrm{~kg})\end{array}$ & $\begin{array}{l}\text { Aggregate } \\
20 \mathrm{~mm}(\mathrm{~kg})\end{array}$ & $\begin{array}{l}\text { Water } \\
\text { (litter) }\end{array}$ \\
\hline $\mathbf{M i x}_{\mathbf{0 . 3 0}}$ & \multirow[t]{3}{*}{0.30} & 375.00 & 00.00 & 750 & 750 & \multirow[t]{3}{*}{112.50} \\
\hline H ix1 & & 337.50 & 37.50 & 750 & 750 & \\
\hline H ix2 & & 300.00 & 75.00 & 750 & 750 & \\
\hline $\mathbf{M i x}_{\mathbf{0 . 3 5}}$ & \multirow[t]{3}{*}{0.35} & 375.00 & 00.00 & 750 & 750 & \multirow[t]{3}{*}{131.25} \\
\hline H ix3 & & 337.50 & 37.50 & 750 & 750 & \\
\hline H ix4 & & 300.00 & 75.00 & 750 & 750 & \\
\hline $\mathbf{M i x}_{0.40}$ & \multirow[t]{3}{*}{0.40} & 375.00 & 00.00 & 750 & 750 & \multirow[t]{3}{*}{150.00} \\
\hline H ix5 & & 337.50 & 37.50 & 750 & 750 & \\
\hline H ix6 & & 300.00 & 75.00 & 750 & 750 & \\
\hline
\end{tabular}

$W=$ Water, $C=$ Cement

\section{EXPERIMENTAL Methodology}

The evaluation of hypo sludge for use as a replacement of cement material begins with the concrete testing. Pervious concrete contains cement, water, coarse aggregate and hypo sludge. In previous concrete $10 \%$ and $20 \%$ of the cement is replaced with hypo sludge. Three cube samples were cast on 
the mould of size $150 * 150 * 150 \mathrm{~mm}$ for each concrete mix with partial replacement of cement with a w/c ratio of $0.30,0.35$, and 0.40 . Three beam samples were cast on the mould of size $100 * 100 * 500$ $\mathrm{mm}$ for each concrete mix with partial replacement of cement with a w/c ratio of $0.30,0.35$, and 0.40 . After about $24 \mathrm{hr}$ the specimens were de-moulded and water curing was continued till the respective specimens were tested after 7,14 and 28 days for compressive strength test and flexural strength test.

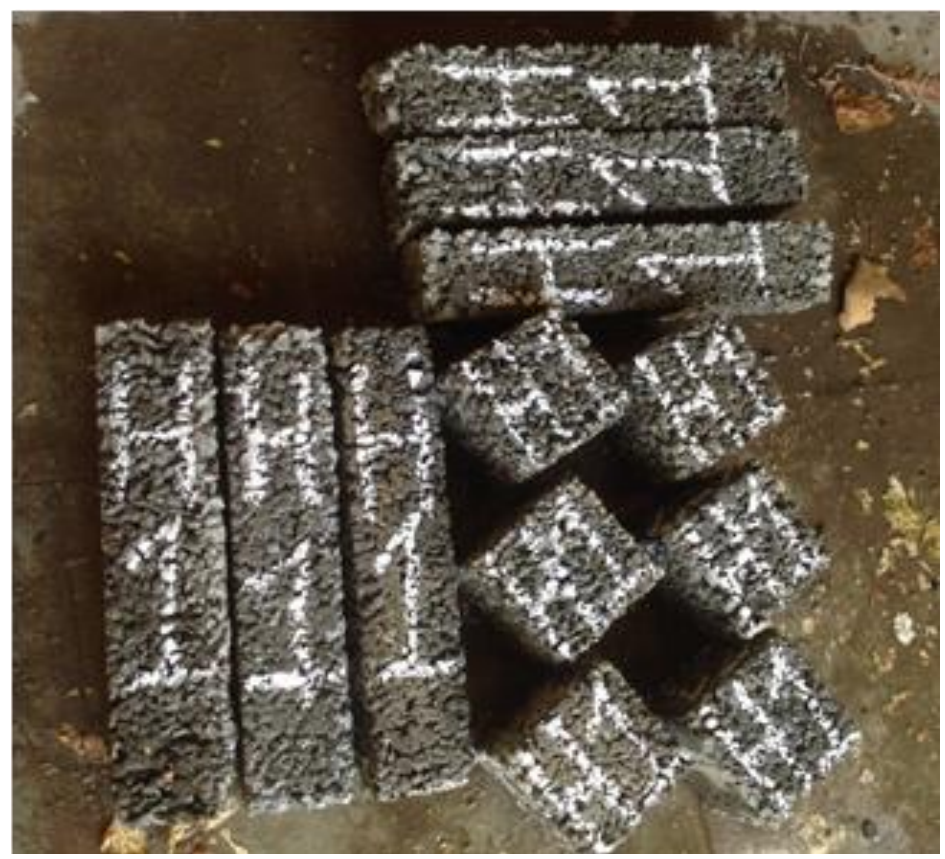

Figure2. Specimens of Pervious Concrete

\subsection{Compressive Strength (IS 516:1959)}

Compressive strength tests were performed on compression testing machine using cube samples. Three samples per batch were tested with the average strength values reported in this paper. The comparative studies were made on each concrete mix for $0.30,0.35$ and $0.40 \mathrm{~W} / \mathrm{C}$ ratio of partial replacement of cement with hypo sludge as $10 \%$ and $20 \%$. Table 8 describe compressive strength of pervious concrete.

\subsection{Flexural Strength (IS 516:1959)}

Flexural strength tests were performed on flexural testing machine using beam samples. Three samples per batch were tested with the average strength values reported in this paper. The flexural studies were made on each concrete mix for $0.30,0.35$ and $0.40 \mathrm{~W} / \mathrm{C}$ ratio of partial replacement of cement with hypo sludge as $10 \%$ and $20 \%$. Table 9 describe flexural strength of pervious concrete.
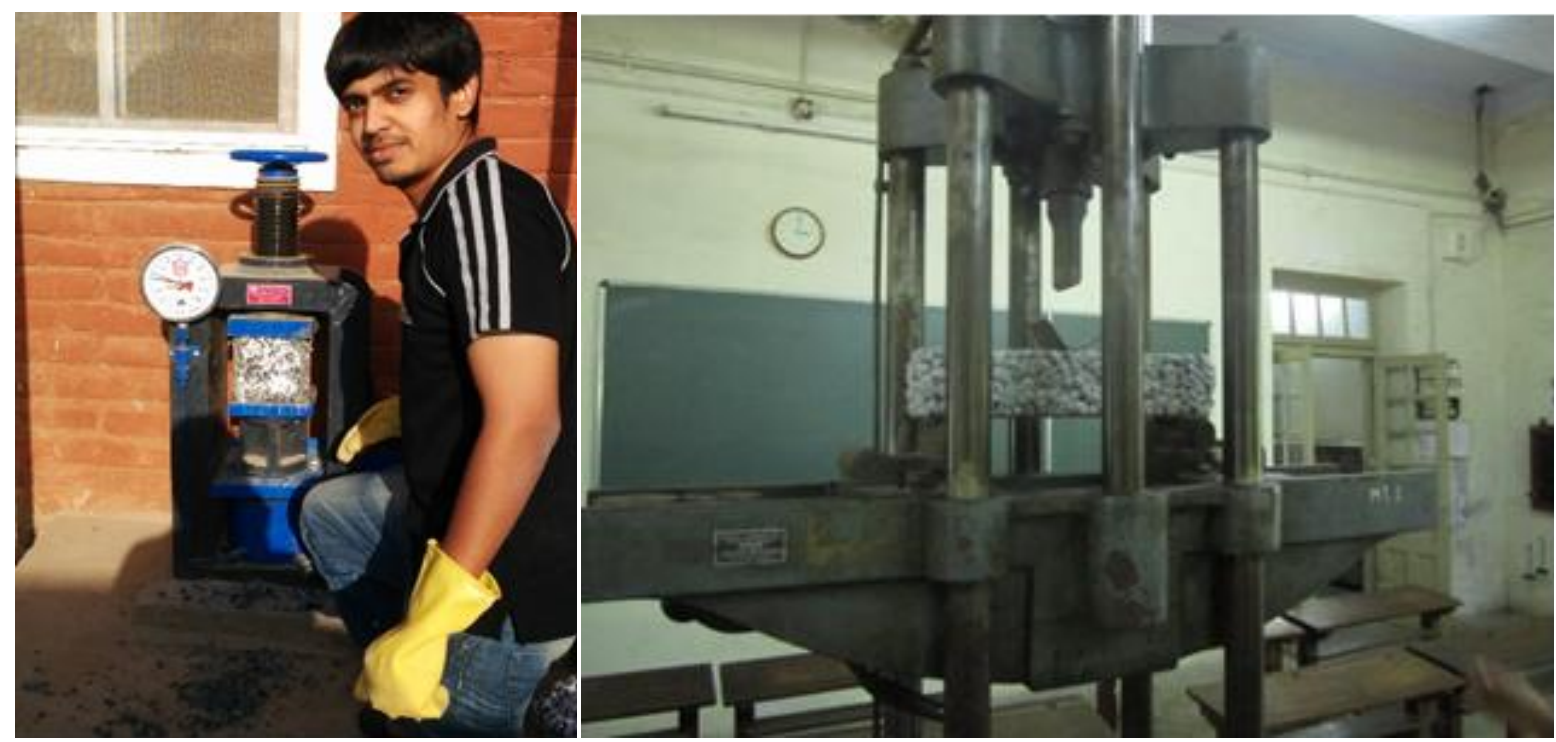

Figure3. Testing of Pervious Concrete 
Innovative Use of Paper Industry Waste (Hypo Sludge) in Pervious Concrete

Table8. Compressive strength of cubes

(150X150X150) AT 7, 14 AND 28 DAYS

\begin{tabular}{|c|c|c|c|c|c|}
\hline \multirow[t]{2}{*}{ Concrete Mix } & \multirow[t]{2}{*}{ W/C ratio } & \multirow{2}{*}{$\begin{array}{l}\text { \% Replacement of } \\
\text { Cement }\end{array}$} & \multicolumn{3}{|c|}{ Average Compressive Strength (N/mm²) } \\
\hline & & & 7 Days & 14 Days & 28 Days \\
\hline $\mathbf{M i x}_{\mathbf{0 . 3 0}}$ & \multirow[t]{3}{*}{0.30} & $0 \%$ & 06.72 & 07.40 & 08.02 \\
\hline H Mix1 & & $10 \%$ & 7.95 & 8.47 & 9.12 \\
\hline H Mix2 & & $20 \%$ & 9.47 & 10.15 & 10.55 \\
\hline $\mathbf{M i x}_{\mathbf{0 . 3 5}}$ & \multirow[t]{3}{*}{0.35} & $0 \%$ & 07.13 & 08.20 & 09.42 \\
\hline H Mix3 & & $10 \%$ & 8.40 & 9.23 & 10.50 \\
\hline H Mix4 & & $20 \%$ & 9.87 & 10.74 & 11.75 \\
\hline $\mathbf{M i x}_{0.40}$ & \multirow[t]{3}{*}{0.40} & $0 \%$ & 08.57 & 09.40 & 10.35 \\
\hline H Mix5 & & $10 \%$ & 9.68 & 10.63 & 11.25 \\
\hline H Mix6 & & $20 \%$ & 10.79 & 11.12 & 12.43 \\
\hline
\end{tabular}

$7^{\text {th }}$ day Compressive Strength Vs W/C ratio

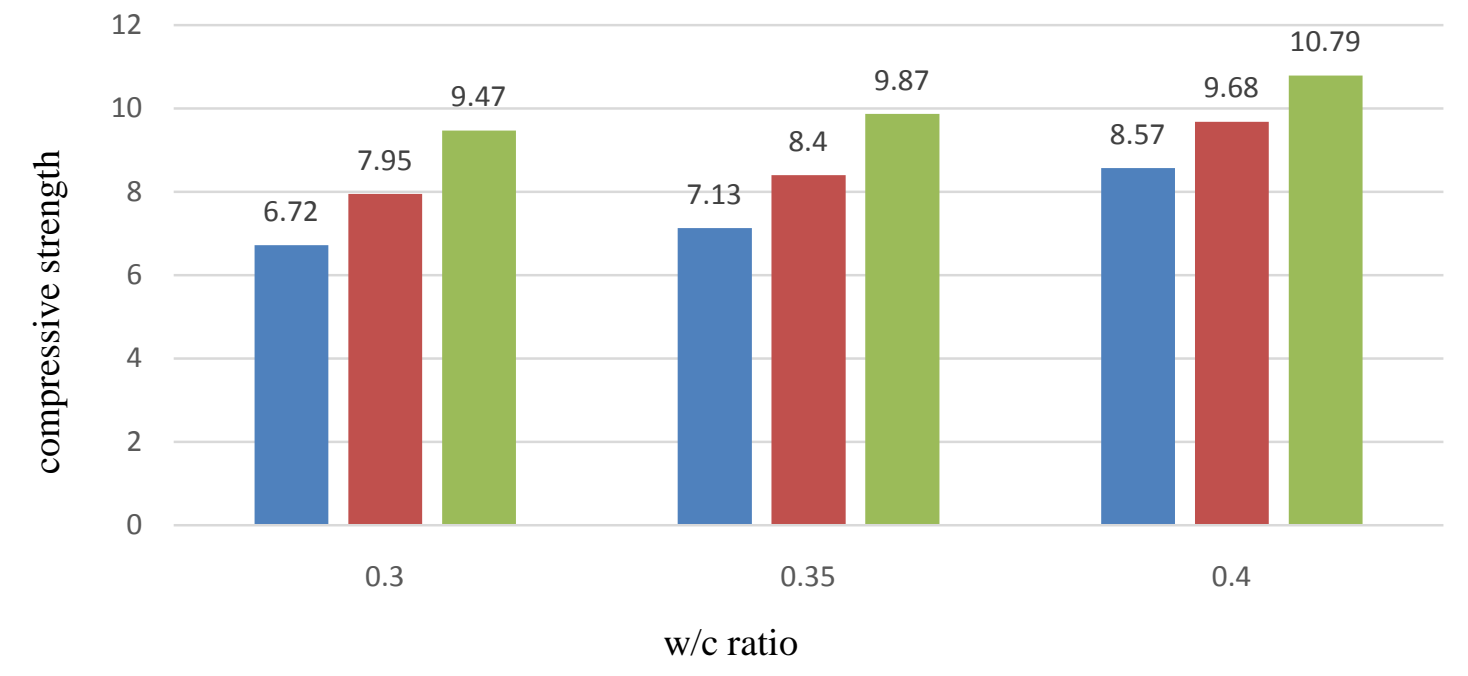

$\square \%$ replacement of cement $\square 10 \%$ replacement of cement $\square 20 \%$ replacement of cement

Figure4. $7^{\text {th }}$ day Compressive Strength Vs W/C ratio

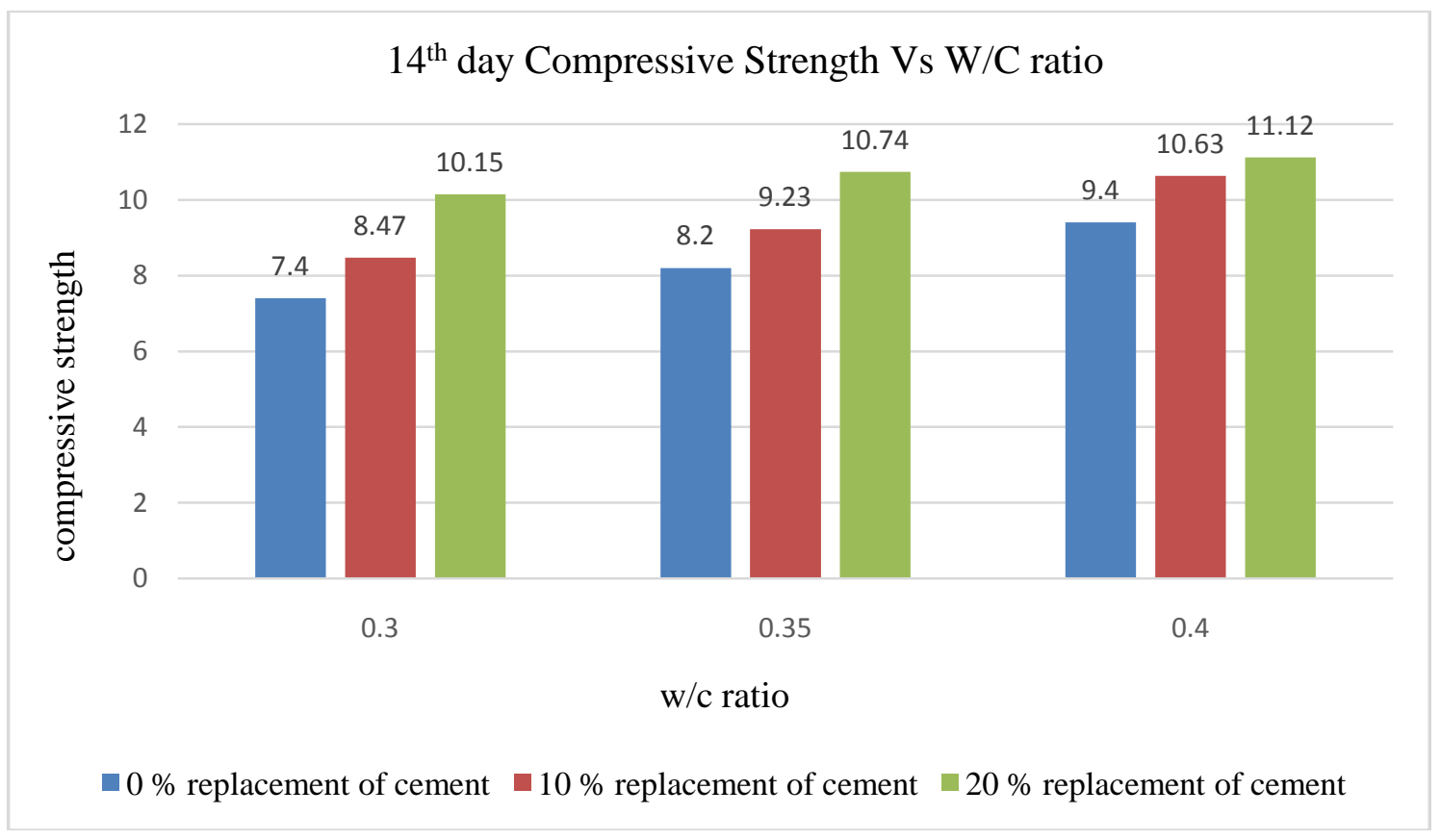

Figure5. $14^{\text {th }}$ day Compressive Strength Vs W/C ratio 


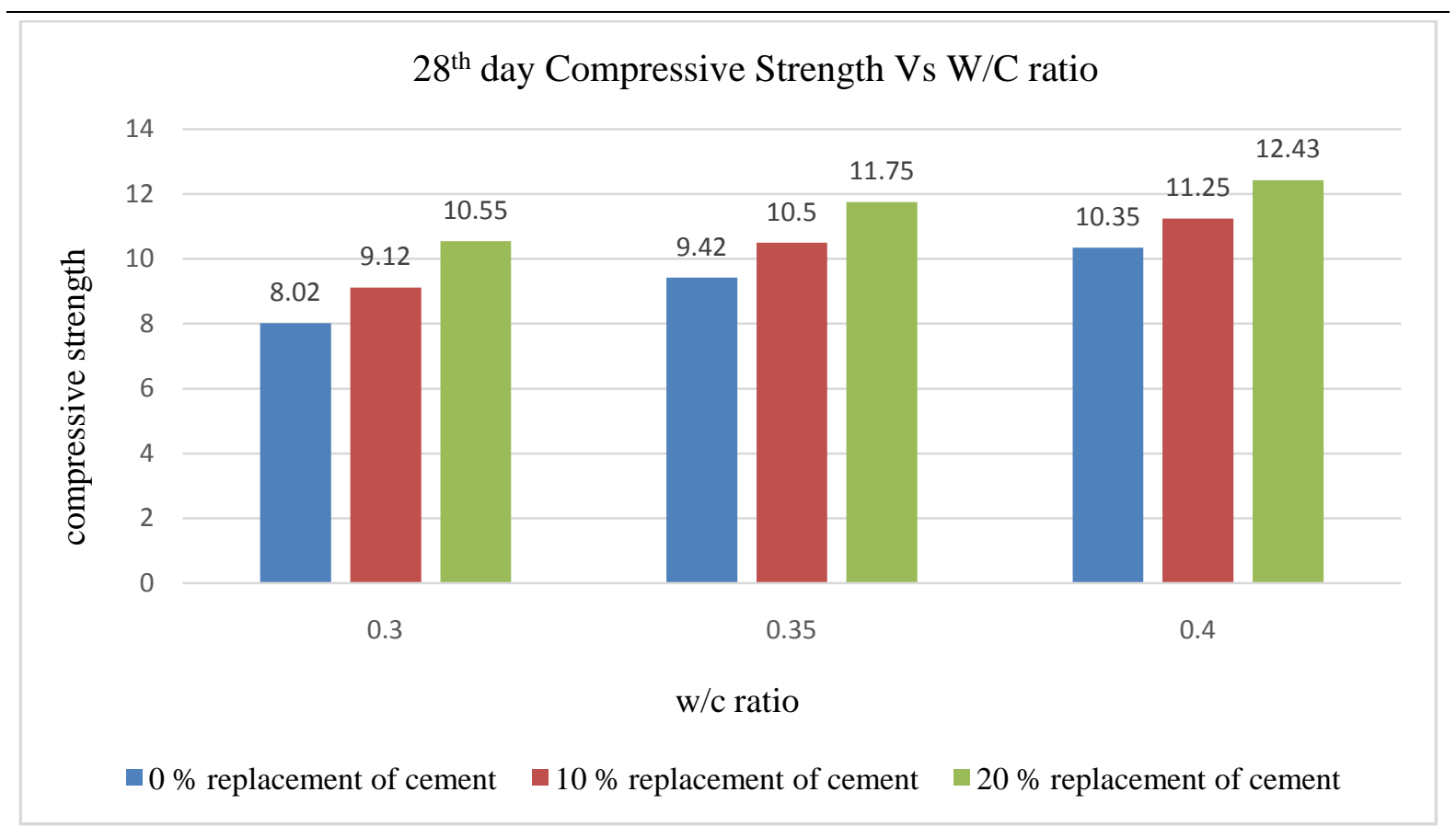

Figure6. $28^{\text {th }}$ day Compressive Strength Vs W/C ratio

Table9. Flexural strength of beams (100x100x500)

AT 7, 14 AND 28 DAYS

\begin{tabular}{|c|c|c|c|c|c|}
\hline \multirow{2}{*}{$\begin{array}{l}\text { Concrete } \\
\text { Mix }\end{array}$} & \multirow{2}{*}{$\begin{array}{l}\mathrm{W} / \mathrm{C} \\
\text { ratio }\end{array}$} & \multirow{2}{*}{$\begin{array}{l}\text { \% Replacement } \\
\text { of Cement }\end{array}$} & \multicolumn{3}{|c|}{ Average Flexural Strength $\left(\mathrm{N} / \mathrm{mm}^{2}\right)$} \\
\hline & & & 7 Days & 14 Days & 28 Days \\
\hline $\mathbf{M i x}_{0.30}$ & \multirow[t]{3}{*}{0.30} & $0 \%$ & 1.14 & 1.30 & 1.49 \\
\hline H Mix1 & & $10 \%$ & 1.25 & 1.55 & 1.98 \\
\hline H Mix2 & & $20 \%$ & 1.47 & 1.98 & 2.52 \\
\hline $\mathbf{M i x}_{\mathbf{0 . 3 5}}$ & \multirow[t]{3}{*}{0.35} & $0 \%$ & 1.40 & 1.58 & 1.85 \\
\hline H Mix3 & & $10 \%$ & 1.52 & 1.87 & 2.15 \\
\hline H Mix4 & & $20 \%$ & 1.85 & 2.05 & 2.56 \\
\hline $\mathbf{M i x}_{\mathbf{0 . 4 0}}$ & \multirow[t]{3}{*}{0.40} & $0 \%$ & 1.89 & 2.15 & 2.43 \\
\hline H Mix 5 & & $10 \%$ & 2.12 & 2.55 & 3.12 \\
\hline H Mix6 & & $20 \%$ & 2.75 & 3.07 & 3.52 \\
\hline
\end{tabular}

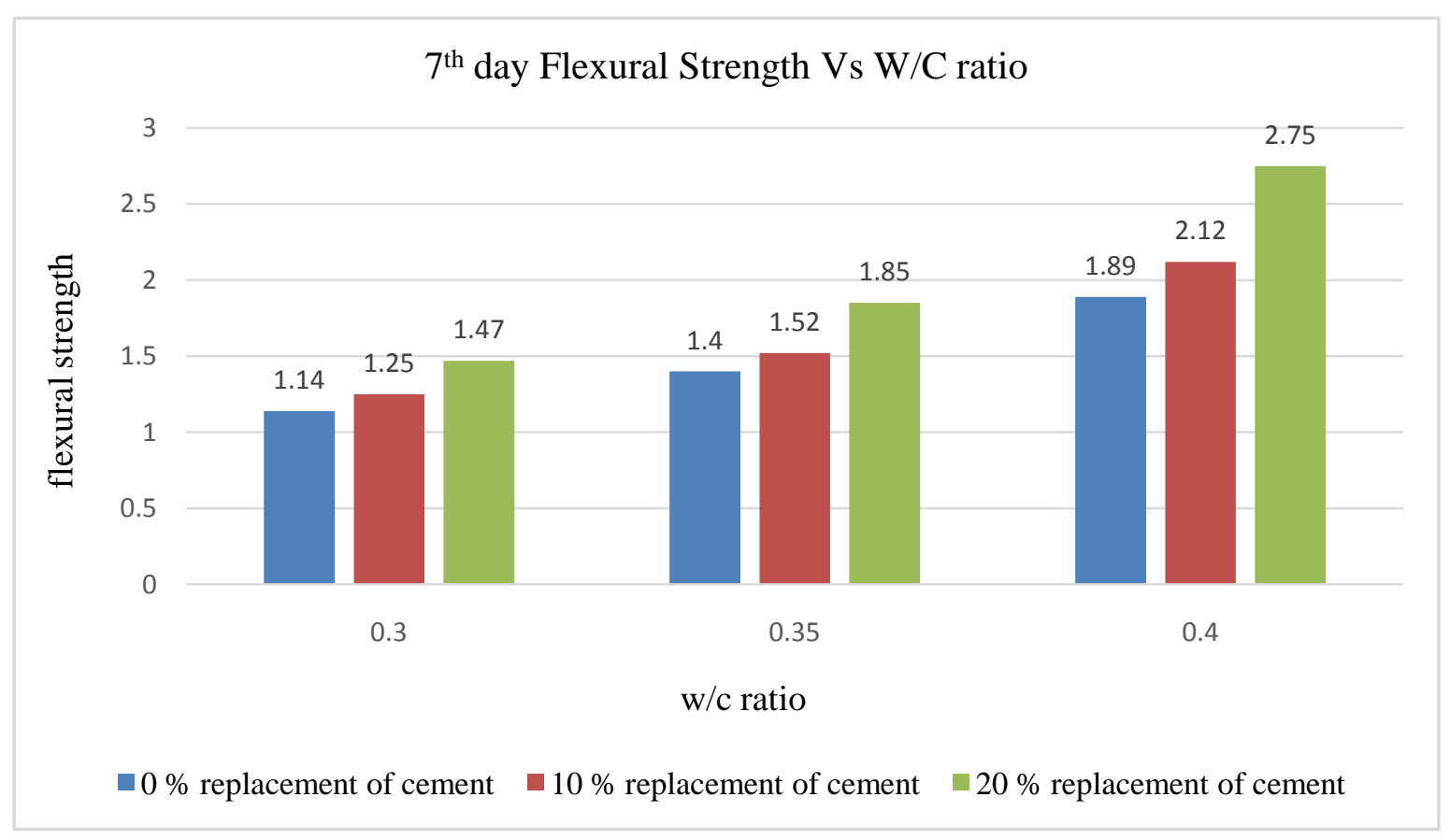

Figure7. $7^{\text {th }}$ day Flexural Strength Vs W/C ratio 


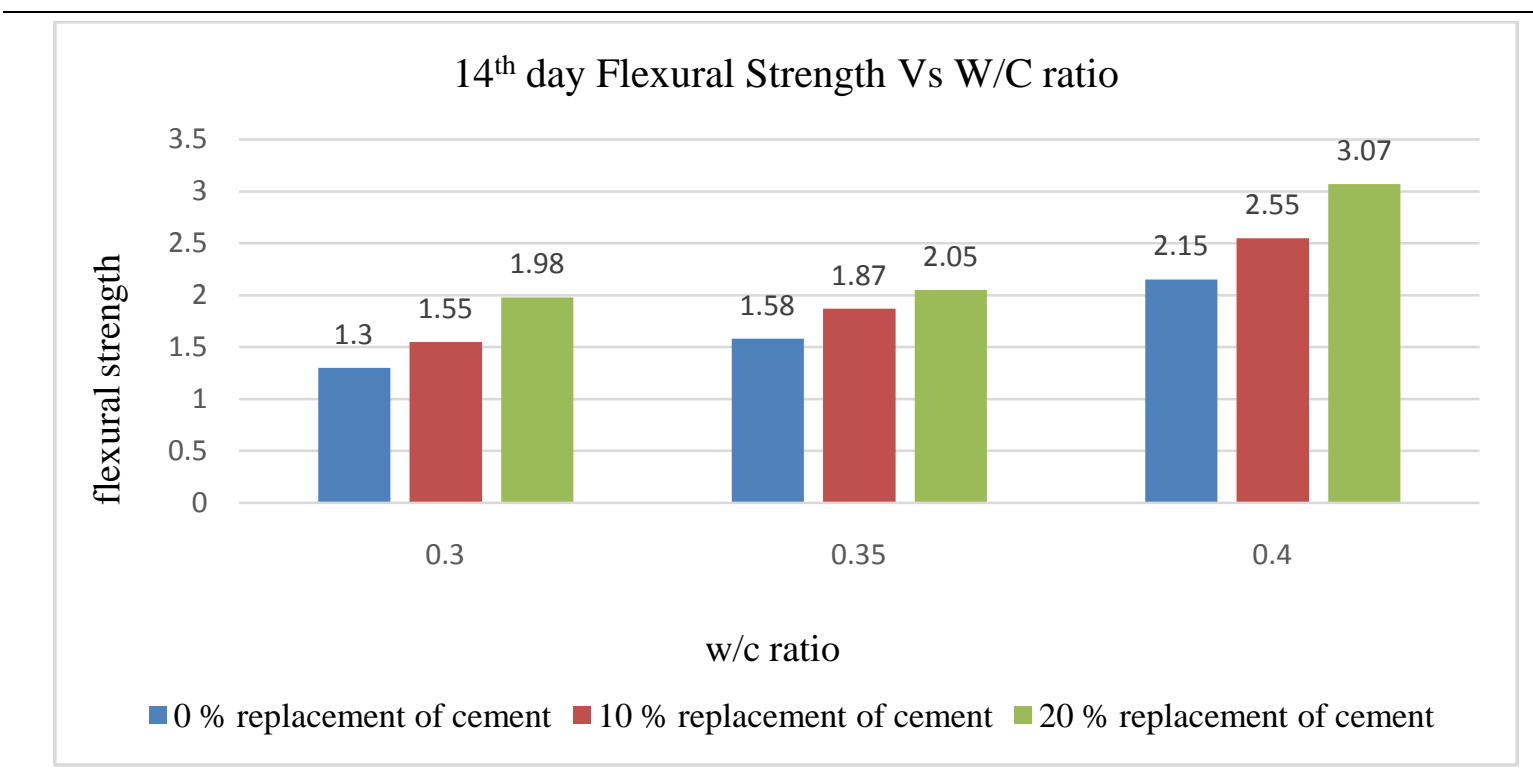

Figure8. $14^{\text {th }}$ day Flexural Strength Vs W/C ratio

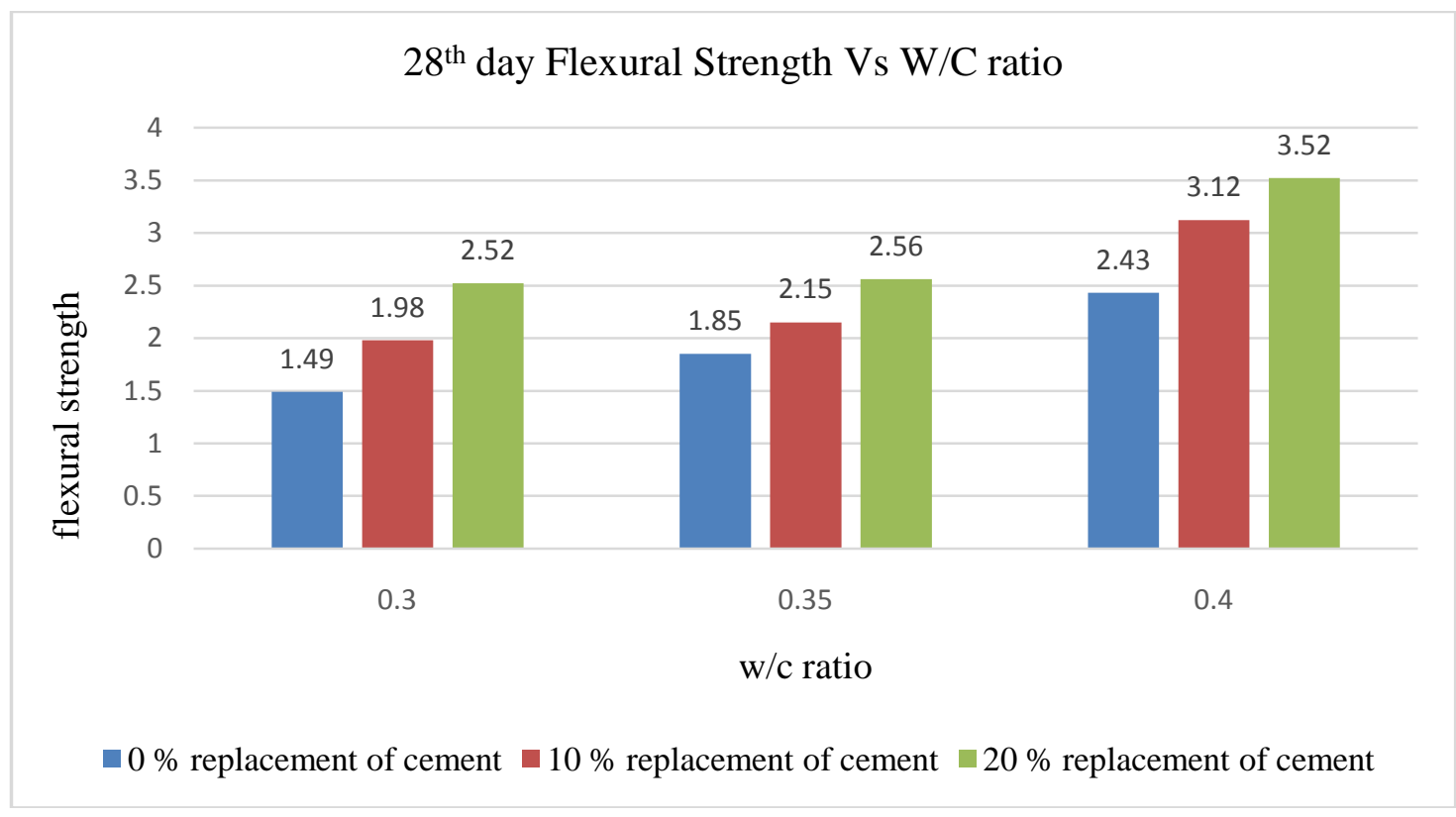

Figure9. $28^{\text {th }}$ day Flexural Strength Vs W/C ratio

\section{Conclusion}

Based on experimental investigations concerning the compressive strength and flexural strength of Pervious Concrete, the following observations are made:

- The Compressive Strength of Pervious Concrete is increases when the replacement of Cement with Hypo Sludge up to $20 \%$ replaces by weight of Cement.

- The Flexural Strength of Pervious Concrete is increases when the replacement of Cement with Hypo Sludge up to $20 \%$ replaces by weight of Cement.

- When W/C ratio is increase respectively, Compressive Strength and Flexural Strength of Pervious Concrete is increase.

- Hypo Sludge is a better innovative supplementary cementitious construction material which is used in concrete, so it can save the paper industries waste disposal costs and produce a 'greener' concrete for construction.

- This research concludes that hypo sludge can be innovative supplementary cementitious Construction Material in Pervious Concrete but judicious decisions are to be taken by engineers. 


\section{ACKNOWLEDGMENT}

The Authors thankfully acknowledge to Dr. C. L. Patel, Chairman, Charutar Vidya Mandal, Er. V. M. Patel, Hon. Jt. Secretary, Charutar Vidya Mandal, Dr. F.S.Umrigar, Principal, B.V.M. Engineering College, Dr. L. B. Zala, Head and Professor, Civil Engineering Department, Prof. J. J. Bhavsar, Associate Professor, Civil Engineering Department, B.V.M. Engineering College, Vallabh Vidyanagar, Gujarat, India for their motivations and infrastructural support to carry out this research.

\section{REFERENCES}

[1] Ajamu S.O., Jimoh A.A., Oluremi J.R., "Evaluation of Structural Performance of Pervious Concrete in Construction", International Journal of Engineering and Technology, ISSN: 20493444, Volume 2, No.5, May 2012.

[2] Balamurugan R, Karthickraja R.,"An Experimental Investigation of Partial Replacement of Cement by Industrial Waste (Hypo Sludge)",International Journal of Engineering Research and Applications", ISSN : 2248-9622, Volume 4, Issue 4 (Version 1), April 2014, PP 430-435.

[3] Jing Yang, Guoliang Jiang,"Experimental Study on Properties of Pervious Concrete Pavement Materials", Cement and Concrete Research 33, Pg. 381-386, 2003.

[4] Jayraj Vinodsinh Solanki, Jayeshkumar Pitroda (2013) "Flexural Strength of Beams by Partial Replacement of Cement with Fly Ash and Hypo Sludge in Concrete" International Journal of Engineering Science and Innovative Technology (IJESIT) Volume 2, Issue 1, ISSN: 2319-5967 ISO 9001:2008 Certified pp-173-179.

[5] Jayraj Vinodsinh Solanki, Jayeshkumar Pitroda (2013) "Investigation of Low Cost Concrete Using Industrial Waste as Supplementary Cementitious Materials" International Journal of Engineering Science and Innovative Technology (IJESIT) Volume 2, Issue 1, ISSN: 2319-5967 ISO 9001:2008 Certified, pp-81-88.

[6] Mamta B. Rajgor, Prof. Jayeshkumar Pitroda (2013) "A Study on Paper Industry Waste: Opportunities for Development of Low Cost Concrete in Indian Context" IJSR - International Journal of Scientific Research, Volume 2 Issue 2, ISSN No 2277 - 8179/ 90-92.

[7] Nadgouda Kshitija, Ghadib Pratik, Gharat Manish, Revati Gurav, Margaje Tejal, Shirke Eesha,"The Use of Pervious Concrete in Rainwater Management", $4^{\text {th }}$ Nirma University International Conference on Engineering 2013.

[8] Patel Ritesh A., Jamnu M. A., "Experimental Study of Concrete Made with Hypo Sludge and Silica Fume", International Journal of Futuristic Trends in Engineering and Technology, ISSN: 2348-5264, Vol. 1 (03), 2014.

[9] Patel Ritesh A., Jamnu M.A., "Experimental Study of Concrete Made with Hypo Sludge", Journal of International Academic Research for Multidisciplinary, Impact Factor 1.393, ISSN: 2320-5083, Volume 2, Issue 2, March 2014.

[10] Pitroda Jayeshkumar, Zala L. B., Umrigar F. S., "Hypo Sludge Management: Opportunities for Developing Low Cost Concrete with Glass Fibres", Global Research Analysis, ISSN 2277-8160, Volume 1, Issue 7, Dec 2012.

[11] Pitroda Jayeshkumar, Zala L. B., Umrigar F. S, "Innovative use of Paper Industry Waste (Hypo Sludge) in Design Mix Concrete", International Journal of Advanced Engineering Technology, E-ISSN 0976-3945, Volume 4, Issue 1, Jan. -Mar 2013, PP 31-35.

[12] Pitroda Jayeshkumar, Zala L. B., Umrigar F. S, "Utilization of Hypo Sludge by Eco-Efficient Development of Rigid Pavement in Rural Roads", International Journal of Engineering Trends and Technology (IJETT), Volume 4 Issue 9, Sep 2013.

[13] Pitroda Jayeshkumar, Zala L. B., Umrigar F. S, "Hypo Sludge: Opportunities for Sustainable Development of Low Cost Rural Roads", International Journal of Civil Engineering and Technology (IJCIET), ISSN 0976 - 6308, Volume 4, Issue 5, September - October 2013.

[14] Tennis Paul, Leming Michael L., Akers David J., "Pervious Concrete Pavements" Portland Cement Association, national ready mixed concrete association, 2004.

[15] Yadav Neetu B., Shah Jayesh A., Shah Rushabh A., "Pervious Concrete: Solution for Low Cost Construction", International Journal of Innovative Science and Modern Engineering, ISSN: 2319-6386, Volume 1, Issue 10, September 2013. 
[16] Darshan S. Shah, Prof. Jayeshkumar Pitroda, Prof. J. J. Bhavsar (2013), "Pervious Concrete: New Era for Rural Road Pavement" International Journal of Engineering Trends and Technology (IJETT), ISSN: 2231-5381, Volume-4, Issue-8, August 2013/3496-3499

[17] Darshan S. Shah, Prof. Jayeshkumar Pitroda (2013), "Assessment for Use of Gravel in Pervious Concrete" International Journal of Engineering Trends and Technology (IJETT), ISSN: 22315381, Volume-4, Issue 10, Oct 2013/4306-4310

[18] Darshan S. Shah, Prof. Jayeshkumar Pitroda (2014), "An Experimental Study on Hardened Properties of Pervious Concrete", Journal of International Academic Research For Multidisciplinary (JIARM), ISSN: 2320-5083, Volume 2, Issue 3, April 2014, PP-332-338 Peer Reviewed Journal, Journal Impact Factor (2014): 1.393

[19] Siddharth Talsania, Prof. Jayeshkumar Pitroda, Prof. Chetna M. Vyas (2015), "A Review of Pervious Concrete by Using Various Industrial Waste Materials", Journal of International Academic Research For Multidisciplinary (JIARM), ISSN: 2320-5083, Volume 2, Issue 12, January 2015, PP-142-151 Peer Reviewed Journal, Journal Impact Factor (2015): 1.625

[20] Siddharth Talsania, Prof. Jayeshkumar Pitroda, Prof. Chetna M. Vyas (2015), "Effect of Rice Husk Ash on Properties of Pervious Concrete", International Journal of Advanced Engineering Research and Studies (IJAERS), E-ISSN2249-8974, Int. J. Adv. Engg. Res. Studies/IV/II/Jan.March,2015/PP:296-299.

\section{AUTHORS' BIOGRAPHY}

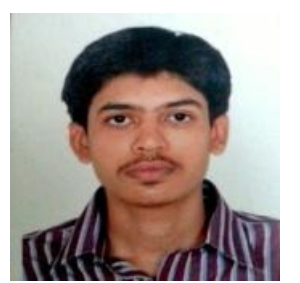

Er. Siddharth Talsania, was born in 1991 in Rajkot City. He received his Bachelor of Engineering degree in Civil Engineering from the L.J. Institute of Engineering and Technology, Gujarat Technological University, in 2013 and Masters of Engineering in Construction Engineering \& Management from Birla Vishvakarma Mahavidyalaya, Gujarat Technological University. At present, he is working, as director in Rajtrishul Construction Company Pvt. Ltd., which is, recognize as a Government Approved "AA" Class Contractor.

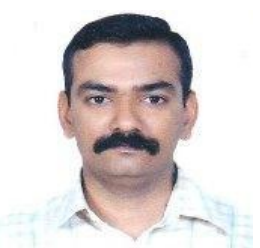

Dr. Jayeshkumar R. Pitroda, received his Bachelor of Engineering degree in Civil Engineering from the Birla Vishvakarma Mahavidyalaya, Sardar Patel University in 2000. In 2009 he received his Master's Degree in Construction Engineering and Management from Birla Vishvakarma Mahavidyalaya, Sardar Patel University. In 2015 he received his Doctor of Philosophy (Ph.D.) Degree in Civil Engineering from Sardar Patel University He joined Birla Vishvakarma Mahavidyalaya Engineering College as a faculty in 2009, where he is Assistant Professor of Civil Engineering Department with a total experience of 16 years in the field of Research, Designing and education. He is guiding M.E. (Construction Engineering \& Management) Thesis work in the field of Civil/Construction Engineering. He has published many papers in National/ International Conferences and International Journals. 